\title{
Jatropha curcas Linn. Response on Nitrogen Deficiency
}

\author{
Herdhata Agusta $^{\mathrm{ab}}$, Fifin Nashirotun Nisya ${ }^{\mathrm{b} *}$ \\ ${ }^{a}$ Agronomy and Horticulture Departement, Bogor Agricultural University. Jl. Meranti Kampus IPB Darmaga \\ Bogor, 16680 - Indonesia \\ ${ }^{\mathrm{b}} \mathrm{Surfactant}$ and Bioenergy Research Center, Bogor Agricultural University. Jl. Pajajaran No.1, Bogor, 16144. West Java. Indonesia
}

\begin{abstract}
Jatropha curcas development was intended in marginal areas. However, jatropha productivity is still low. It needs adequate nutrient to increase jatropha productivity . This research was undertaken to determine the response of Jatropha on $\mathrm{N}$ deficiency and selecting accessions in order Jatropha to grow well in $\mathrm{N}$ deficiency condition. The research was done on nutrient culture in 2011. Eleven accession from Indonesia and one accession from Thailand were observed. From the observation, Jatropha need nitrogen to grow. $\mathrm{N}$ deficiency reduced leaf number and plant height . $\mathrm{N}$ deficiency increasing root length except accessions of IP-1M, Parung Panjang 4, Banten and Lombok. Bima F, Dompu. Banten 1-3-1 and Aceh Besar had better growth in N deficiency that can be measured from the biomass weight and the root length.
\end{abstract}

Keywords: Jatropha; nutrient culture; $\mathrm{N}$ deficiency; productivity.

\section{Introduction}

Prospects for Jatropha (Jatropha curcas Linn) as biofuels feedstock to support biofuel development is inline with the government policy on renewable energy. The gross energy content from Jatropha oil ranges between (30.1 to 45.8) $\mathrm{MJ} \cdot \mathrm{kg}^{-1}$ [1-5]. The presence of some anti-nutritional factors such as toxic phorbol esters and a high content of stearic acid (7\%) render Jatropha oil unfit for edible purposes [6]. Since jatropha is considered a low input crop, implicating a low energy use for fertilisers, tillage and so on, the life-cycle carbon dioxide emissions for biodiesel can be low, likely less than $15 \%$ compared to petro-diesel [5]. But, in fact, Jatropha needs more inputs like nitrogen and phosphates to improve the yields. Application of nitrogren fertilizer proved to be beneficial for Jatropha, treatment of N $50 \mathrm{~g}$ each plant and $60 \mathrm{~g}$ each plant N resulted in consistent higher yield of seed oil [7]. Another research also shown that the highest value of dry matter $\left(617.3 \mathrm{~g} \cdot \mathrm{m}^{-2}\right)$ and oil $\left(358 \mathrm{~g} \cdot \mathrm{m}^{-2}\right)$ from jatropha were obtained from the fertiliser treatment of $70 \mathrm{~kg} \cdot \mathrm{ha}^{-1}$ of $\mathrm{N}, 120 \mathrm{~kg} \cdot \mathrm{ha}^{-1}$ of P and $150 \mathrm{~kg} \cdot \mathrm{ha}^{-1}$ mof K than without fertiliser [8]. Nitrogen makes up about $12.35 \%$ of jatropha dry weight [2], and has so many roles in proteins, nucleic acids, and many other macromolecules that the primary effect of nitrogen deficiency is stunted growth. Because nitrogen is necessary for chlorophyll formation but can be easily moved in the plant, another obvious symptom is yellowing of older leaves $[9,10]$.

The use of conventional crops like cassava and sugarcane for biofuels production has recently been of concern because they can compete with food materials and should be planted in favoured land. However, Indonesia has $37.123 \mathrm{~km}^{2}$ of marginal land [11]. These considerations have encouraged Indonesian Government to search for an

* Corresponding author. Tel.: +62 251833 0970; fax: +62 2518330977.

E-mail address: fifin.nisya@gmail.com 
alternative approach to biofuels feedstock supply like growing non-edible crops on marginal lands. Using these lands to grow energy crops, even though the lands are less productive, can provide some additional environmental and social benefits, including restoration of degraded land, carbon sequestration, and job creation. Although jatropha can grow in marginal land, well growing and high yielding variety in nitrogen deficiencies land should be found. Therefore the present study was undertaken to determine the response of Jatropha on $\mathrm{N}$ deficiency and selecting accessions were able to grow well in $\mathrm{N}$ deficiency condition.

\section{Material and mehod}

This research was conducted using nutrient culture method at greenhouses of Surfactant and Bioenergy Research Center of Bogor Agricultural University in 2011. Selection was done on 11 Jatropha accessions from Indonesia (Dompu, G Tambra, Bima F, IP-1M, Parung Panjang 4, Banten 1-4-1, Banten 1-3-1, Banten 3-2-1, Banten, Lombok and Aceh Besar) and one accession from Thailand during the vegetative period. The 20 das (days after sowing), of jatropha seedlings were transplanted into $5 \mathrm{dm}^{3}$ pots, one plant per pot which filled with nutrient solution [12] containing $4 \mathrm{mM} \mathrm{KNO}_{3}, 4 \mathrm{mM} \mathrm{Ca}\left(\mathrm{NO}_{3}\right)_{2}, 1.5 \mathrm{mM} \mathrm{MgSO}_{4}, 0.5 \mathrm{mM} \mathrm{NaH}_{2} \mathrm{PO}_{4}$, with micronutrients present in the following concentrations: $100 \mu \mathrm{M} \mathrm{Fe}, 46 \mu \mathrm{M} \mathrm{B}, 1.8 \mu \mathrm{M} \mathrm{Mn}, 0.8 \mu \mathrm{M} \mathrm{Zn}, 0.3 \mu \mathrm{M} \mathrm{Cu}, 0.7 \mu \mathrm{M} \mathrm{Mo}$, and $0.2 \mu \mathrm{M}$ Co. The experiment arranged in a completely randomized design. Temperatures were between (26 to 36$){ }^{\circ} \mathrm{C}$ during the day. While the humidity was about $80 \%$ on average.

At 34 das, nutrient solution was replace with $4 \mathrm{dm}^{3}$ of a $\mathrm{N}$-free nutrient solution $\left(\mathrm{KNO}_{3}\right.$ and $\left.\mathrm{Ca}\left(\mathrm{NO}_{3}\right)_{2}\right)$ replaced by $\mathrm{KCl}$ and $\mathrm{CaCl}_{2} \cdot 2 \mathrm{H}_{2} \mathrm{O}$ by rinsing the pots 3 times with $1 \mathrm{dm}^{3}$ of aquadest. Plants maintained in nutrient culture for 1.5 mo from Dec. 2010 to Jan. 2011.

Observed parameters were leaf number, plant height, stem diameter, leaf length, leaf width, root length and biomass weight prior to the given treatment and after given treatment. All data from the measurement was analyzed using SAS software 9.1.3 Portable.

\section{Result and discussion}

From the observation, jatropha growth was effected by the $\mathrm{N}$ deficiency in nutrient culture. The absence of nitrogen effected on leaf development, stem growth, root development and biomass growth. Jatropha accessions affect the ability of plants to respond to $\mathrm{N}$ deficiency.The respon was varied within accessions.

\subsection{Leaf development}

Effect of $\mathrm{N}$ deficiency on leaf development of jatropha is shown in Table 1. All jatropha accessions can not increased their leaf number. Before the seedling transplanted into selection nutrient culture, the accessions have 4,02 leaves on average, but in the end of the observation the accessions have three leaves on average. Mostly, the accessions abort their leaves except IP-1M and Banten. Similar result also shown on [13], N deficiency caused a decrease in the rate of main stem leaf emergence of narrow leaf Lupin. From the observation, the leaves of some accessions become yellow. A N shortage caused a lack of chlorophyll and leaves become yellow $[9,10,14]$.

Beside leaf number and emergence, leaf size of the jatropha accession also performed by measured the leaf length and leaf width. Final size of individual leaves on the main stem was also affected by $\mathrm{N}$ treatment. Leaf lenght for all accession was $7 \mathrm{~cm}$ on average while the leaf width was $6.4 \mathrm{~cm}$ on average for all accessions. A high sensitivity of leaf growth to nitrogen availability has been demonstrated in many studies. [15] showed that the leaf size is very responsive to nitrogen supply. The leaf size been largely a result of cell production and cell expansion on sunflower. 
Table 1. Effect of $\mathrm{N}$ deficiency on leaf development of Jatropha.

\begin{tabular}{|c|c|c|c|c|c|c|c|c|c|c|}
\hline \multirow{2}{*}{$\begin{array}{l}\text { Accession } \\
\text { Dompu }\end{array}$} & \multicolumn{2}{|c|}{$\begin{array}{l}\text { Leaf number } \\
\text { before } \\
\text { transplanted }(\mathrm{cm})\end{array}$} & \multicolumn{2}{|c|}{$\begin{array}{l}\text { Leaf number after } \\
\text { transplanted }(\mathrm{cm})\end{array}$} & \multirow{2}{*}{$\begin{array}{l}\begin{array}{l}\text { Leaf length } \\
\text { before } \\
\text { transplanted } \\
(\mathrm{cm})\end{array} \\
1.3\end{array}$} & \multicolumn{2}{|c|}{$\begin{array}{l}\text { Leaf length after } \\
\text { transplanted }(\mathrm{cm})\end{array}$} & \multirow{2}{*}{$\begin{array}{l}\begin{array}{l}\text { Leaf width } \\
\text { before } \\
\text { transplanted } \\
(\mathrm{cm})\end{array} \\
1.2\end{array}$} & \multicolumn{2}{|c|}{$\begin{array}{l}\text { Leaf width after } \\
\text { transplanted }(\mathrm{cm})\end{array}$} \\
\hline & 4.0 & bc & 3.3 & $\mathrm{~b}$ & & 7.6 & $a b$ & & 7.0 & $a b$ \\
\hline G Tambora & 3.5 & $\mathrm{bc}$ & 3.0 & $\mathrm{~b}$ & 1.7 & 8.0 & $a b$ & 1.6 & 6.6 & $a b$ \\
\hline Bima F & 7.3 & $\mathrm{a}$ & 4.0 & a & 2.2 & 6.4 & $a b c$ & 1.5 & 7.0 & $a b$ \\
\hline IP-1M & 4.0 & $\mathrm{bc}$ & 4.0 & $\mathrm{~b}$ & 1.9 & 6.2 & bcd & 1.2 & 7.3 & $a b$ \\
\hline ParungPanjang4 & 3.5 & $\mathrm{bc}$ & 3.0 & $\mathrm{~b}$ & 1.2 & 8.4 & $\mathrm{a}$ & 1.1 & 5.9 & $a b c$ \\
\hline Banten I-4-1 & 4.0 & bc & 3.3 & $\mathrm{~b}$ & 1.8 & 8.4 & $\mathrm{a}$ & 1.7 & 6.5 & $a b$ \\
\hline Banten I-3-1 & 4.8 & $\mathrm{~b}$ & 3.5 & $\mathrm{~b}$ & 2.1 & 6.4 & $a b c$ & 2.1 & 6.6 & $a b$ \\
\hline Banten 3-2-1 & 4.8 & $\mathrm{~b}$ & 3.3 & $\mathrm{~b}$ & 3.1 & 7.1 & $a b c$ & 3.0 & 6.5 & $a b$ \\
\hline Banten & 2.2 & $\mathrm{c}$ & 2.5 & $\mathrm{bc}$ & 1.3 & 6.6 & $a b c$ & 1.0 & 5.7 & $\mathrm{bc}$ \\
\hline Lombok & 2.2 & $\mathrm{c}$ & 2.0 & $\mathrm{c}$ & 2.0 & 4.4 & d & 1.9 & 4.8 & $\mathrm{c}$ \\
\hline Thailand & 4.5 & $\mathrm{~b}$ & 3.2 & $\mathrm{~b}$ & 1.7 & 8.0 & $a b$ & 1.8 & 7.3 & a \\
\hline Aceh Besar & 3.5 & bc & 3.0 & $\mathrm{~b}$ & 2.5 & 5.6 & $\mathrm{~cd}$ & 2.0 & 5.7 & $\mathrm{bc}$ \\
\hline Average & 4.0 & & 3.2 & & 1.9 & 7.0 & & 1.7 & 6.4 & \\
\hline
\end{tabular}

The numbers in each column followed by the same letter are not significantly different

Table 2. Effect of N deficiency on stem growth of Jatropha.

\begin{tabular}{|c|c|c|c|c|c|c|c|c|}
\hline \multirow{2}{*}{$\begin{array}{l}\text { Accession } \\
\text { Dompu }\end{array}$} & \multicolumn{2}{|c|}{$\begin{array}{l}\text { Plant height before } \\
\text { transplanted }(\mathrm{cm})\end{array}$} & \multicolumn{2}{|c|}{$\begin{array}{l}\text { Plant height after } \\
\text { transplanted }(\mathrm{cm})\end{array}$} & \multicolumn{2}{|c|}{$\begin{array}{l}\text { Stem diameter before } \\
\text { transplanted }(\mathrm{cm})\end{array}$} & \multicolumn{2}{|c|}{$\begin{array}{l}\text { Stem diameter before } \\
\text { transplanted }(\mathrm{cm})\end{array}$} \\
\hline & 20.8 & a & 20.0 & $a b$ & 0.5 & $a b c$ & 0.5 & $\mathrm{~b}$ \\
\hline G Tambora & 17.9 & abcd & 17.1 & bcde & 0.4 & $\mathrm{~cd}$ & 0.4 & $\mathrm{bc}$ \\
\hline Bima F & 19.7 & $a b$ & 19.3 & $a b c$ & 0.5 & $a b c$ & 0.7 & $\mathrm{a}$ \\
\hline IP-1M & 20.9 & $\mathrm{a}$ & 21.3 & $\mathrm{a}$ & 0.5 & $a b c$ & 0.7 & $\mathrm{a}$ \\
\hline Parung Panjang 4 & 16.7 & bed & 15.5 & de & 0.5 & $a b$ & 0.4 & $\mathrm{bc}$ \\
\hline Banten I-4-1 & 17.2 & abcd & 16.1 & cde & 0.4 & $\mathrm{~cd}$ & 0.4 & $\mathrm{c}$ \\
\hline Banten I-3-1 & 20.5 & $a b$ & 18.7 & abcd & 0.6 & $\mathrm{a}$ & 0.5 & $\mathrm{~b}$ \\
\hline Banten 3-2-1 & 18.5 & $a b c$ & 17.1 & bcde & 0.5 & $\mathrm{bc}$ & 0.4 & $\mathrm{bc}$ \\
\hline Banten & 15.8 & $\mathrm{~cd}$ & 15.3 & de & 0.3 & $d$ & 0.3 & $\mathrm{c}$ \\
\hline Lombok & 14.7 & $\mathrm{~d}$ & 14.5 & $\mathrm{e}$ & 0.3 & $\mathrm{~d}$ & 0.3 & $\mathrm{c}$ \\
\hline Thailand & 19.2 & $a b c$ & 18.1 & abcd & 0.4 & $\mathrm{bc}$ & 0.4 & $\mathrm{bc}$ \\
\hline Aceh Besar & 20.6 & $\mathrm{a}$ & 19.9 & $a b$ & 0.5 & $a b c$ & 0.5 & $\mathrm{~b}$ \\
\hline Average & 18.5 & & 17.7 & & 0.4 & & 0.4 & \\
\hline
\end{tabular}

The numbers in each column followed by the same letter are not significantly different 


\subsection{Stem growth}

Effect of $\mathrm{N}$ deficiency on stem growth of jatropha is shown in Table 2. A N shortage caused plant stunting. Nitrogen is essential for cell division and enlargement, when it is lacking, plants will be shorter than usual $[9,10,14]$. Only IP-1M can increase the plant height. Before transplanted, the accessions height was $18.5 \mathrm{~cm}$ on average, but after transplanted the accession height was 17.7 on average. $\mathrm{N}$ deficiency also caused all accesions can not increased the stem diameter except Bima and IP-1M. At this stage, a reduction in the number of cells produced accounted for approximately $30 \%$ on average of the reduction in stem growth.

\subsection{Root length and plant biomass weight}

Effect of $\mathrm{N}$ deficiency on root length and plant biomass weight growth of jatropha is shown in Table 3 . The accessions increased their root length $0.4 \mathrm{~cm}$ on average. However, IP-1M, Parung Panjang 4, Banten and Lombok accessions reduced their root length. But the root decreased comparatively less than the shoot, the root-to-shoot ratio increased under decreasing $\mathrm{N}$ supply from 0.27 at the full supply to 0.31 . Similar result also shown on [16] study, provision of the generous $\mathrm{N}$ supply altered the distribution of growth between leaves and roots, with the $\mathrm{N}$-deficient plants having a higher root : leaf or root : needle ratio than the well fertilized trees. Provision of a generous $\mathrm{N}$ supply stimulated root growth, especially at the later harvests, which was reflected mainly in growth of the tap root in sycamore.

At the final harvest, the amount of biomass weight increased $30 \%$ on average. Bima $\mathrm{F}$ accessions can increase biomass weight better than other accesssions but not significantly differ from Dompu, Banten 1-3-1, and Aceh Besar accession.

Table 3. Effect of $\mathrm{N}$ deficiency on root growth and biomass weight of Jatropha

\begin{tabular}{|c|c|c|c|c|c|c|c|c|}
\hline \multirow{2}{*}{$\frac{\text { Accession }}{\text { Dompu }}$} & \multicolumn{2}{|c|}{$\begin{array}{l}\text { Root length before } \\
\text { transplanted }(\mathrm{cm})\end{array}$} & \multicolumn{2}{|c|}{$\begin{array}{l}\text { Root length after } \\
\text { transplanted }(\mathrm{cm})\end{array}$} & \multicolumn{2}{|c|}{$\begin{array}{l}\text { Biomass weight before } \\
\text { transplanted }(\mathrm{g})\end{array}$} & \multicolumn{2}{|c|}{$\begin{array}{l}\text { Biomass weight } \\
\text { after transplanted (g) }\end{array}$} \\
\hline & 4.8 & abcd & 5.6 & $a b c$ & 6.8 & $a b$ & 8.5 & $\mathrm{a}$ \\
\hline G Tambora & 5.2 & abcd & 5.4 & $a b c$ & 2.8 & $\mathrm{c}$ & 5.7 & $\mathrm{bc}$ \\
\hline Bima F & 5.5 & $a b c$ & 6.6 & $a b$ & 6.8 & $a b$ & 9.0 & $\mathrm{a}$ \\
\hline IP-1M & 6.3 & $a b$ & 6.2 & $a b c$ & 6.3 & $a b$ & 7.8 & $a b$ \\
\hline Parung Panjang 4 & 5.3 & abcd & 5.1 & $a b c$ & 5.1 & $a b c$ & 6.0 & $\mathrm{bc}$ \\
\hline Banten I-4-1 & 3.4 & $\mathrm{~cd}$ & 4.1 & $\mathrm{bc}$ & 4.8 & $\mathrm{bc}$ & 6.6 & $a b c$ \\
\hline Banten I-3-1 & 5.6 & $a b c$ & 6.1 & $a b c$ & 7.5 & $\mathrm{a}$ & 8.9 & $\mathrm{a}$ \\
\hline Banten 3-2-1 & 5.4 & abcd & 5.4 & $a b c$ & 6.2 & $a b$ & 7.1 & $a b$ \\
\hline Banten & 3.9 & bcd & 3.7 & $\mathrm{bc}$ & 3.0 & $\mathrm{c}$ & 4.4 & $\mathrm{c}$ \\
\hline Lombok & 2.8 & $\mathrm{~d}$ & 2.7 & $\mathrm{c}$ & 2.8 & $\mathrm{c}$ & 4.3 & $\mathrm{c}$ \\
\hline Thailand & 5.6 & $a b c$ & 6.8 & $a b$ & 6.1 & $a b$ & 7.1 & $a b$ \\
\hline Aceh Besar & 7.3 & $\mathrm{a}$ & 8.0 & $\mathrm{a}$ & 6.9 & $a b$ & 8.5 & $\mathrm{a}$ \\
\hline Average & 5.1 & & 5.5 & & 5.4 & & 7.0 & \\
\hline
\end{tabular}

The numbers in each column followed by the same letter are not significantly different

\section{Conclusion}

From the experiment above, it is conclude that jatropha needs nitrogen to grow. Nitrogen deficiency reduced leaf number and plant height of jatropha. N deficiency increasing root length except IP-1M, Parung Panjang 4, Banten 
and Lombok. Bima F, Dompu, Banten 1-3-1 and Aceh Besar accessions had better growth in N deficiency that can be measured from the biomass weight and the root length.

\section{Acknowledgements}

The authors are highly thankful to the Central Research Intitute of Electric Power Industry (CRIEPI), Japan and Directorate General of Higher Education of Ministry of Education for their supports of this research study.

\section{References}

[1] Makkar HPS, Becker K, Sporer F, Wink M. Studies on nutritive potential and toxic constituents of different provenances of Jatropha curcas. J.Agric.Food Chem 1997; 45:3152-3157.

[2] Openshaw K. A review of Jatropha curcas:an oil plant of unfulfilled promise. Biomass and Energy 2000; 9: 1-15.

[3] Pramanik K. Properties and use of Jatropha curcas oil and diesel fuel blends in compression ignition engine. Renewable energy 2003; 28:239-284.

[4] Forson FK, Oduro EK, Hammond-Donkoh E. Performance of Jatropha oil blends in a diesel engine. Renewable energy 2004;29:1135-1145.

[5] Francis G, Edinger R, Becker K. A concept of simultaneous wasteland reclamation, fuel production, and socio-economic development in degraded areas in India: need, potential and prospectives of Jatropha plantation. Natural Resourcs Forum 2005;29:12-24.

[6] Shah S, Sharma S, Gupta MN. Biodiesel preparation by lipase-catalyzed transesterification of Jatropha oil. Energ. Fuel 2004;18: 154-159.

[7] Mahopatra S, Panda PK. Effects of fertilizer application on growth and yield of Jatropha curcas L. in an aeric tropaquept of Eastern India. Not Sci Biol 2011;3(1):95-100.

[8] Akbarian MM, Modafebehzadi N, Bagheripour MA. Study of fertilizer (NPK) effects on yield and trigliserids in Jatropha curcas (Jatropha curcas). Plant Ecophysiology 2010;2:169-172.

[9] Salisbury FB, Ross C. Plant Physiology $4^{\text {th }}$ ed. Wadsworth, Belmont, CA; 1992.

[10] Bennett WF. Plant nutrient utilization and diagnostic plant symptoms. Pp. 1-7 in W. F. Bennett (Ed.), Nutrient Deficiencies and Toxicities in Crop Plants. APS Press, St. Paul, MN; 1994

[11] APEC Energy Working Group. Assessment of biomass resources from marginal lands in APEC economies. National Renewable Energy Laboratory (NREL). Golden, Colorado, USA; 2009

[12] Jeschke WD, Peuke A, Kirkby EA, Pate JS, Hartung W. Effects of P deficiency on the uptake, flows and utilization of C, N and H2O within intact plant of Ricinus communis L. Journal of Experimental Botany 1996;47: 1737-54.

[13] Ma Q, Longnecker M, Dracup M. Nitrogen deficiency slows leaf development and delays flowering in narrow-leafed Lupin. Annals of Botany 1997;79: 403-409.

[14] Snyder CS. Plant nitrogen deficiency - got symptoms?. International Plant Nutrition Institute. PNT 6; 2011.

[15] Trapáni N, Hall AJ, Weber M. Effects of constant and variable nitrogen supply on sunflower (Helianthus annuusL.) leaf cell number and size. Ann. Botany 1999; 84:.599-606.

[16] Mackie-Dawson LA, Millard P, Proe MF. The effect of nitrogen supply on root growth and development in sycamore and Sitka spruce trees. Forestry 1995; 68 (2): 107-114. 